\title{
PENGARUH MODEL PEMBELAJARAN KOOPERATIF TIPE TAPPS BERBANTUAN LKS OPEN-ENDED TERHADAP KEMAMPUAN PEMECAHAN MASALAH SISWA KELAS XI MIPA
}

\author{
N.L.P. K. W. Lestari' ${ }^{1}$ I. G. N. Y. Hartawan ${ }^{2}$, I P. W. Ariawan ${ }^{3}$ \\ Program Studi Pendidikan Matematika \\ Universitas Pendidikan Ganesha \\ Singaraja, Indonesia \\ e-mail: \{ tikalestari462@gmail.com, hartawan.math@gmail.com, putu wisna ariawan@yahoo.com \}
}

\begin{abstract}
Abstrak
Penelitian ini merupakan penelitian eksperimen semu yang bertujuan untuk mengetahui pengaruh model pembelajaran kooperatif tipe TAPPS berbantuan LKS open-ended terhadap kemampuan pemecahan masalah matematika siswa kelas XI MIPA SMA Negeri 2 Banjar. Desain penelitian yang digunakan dalam penelitian ini adalah post-test only control group design. Populasi penelitian ini adalah siswa kelas XI MIPA SMA Negeri 2 Banjar semester ganjil tahun ajaran 2018/2019 yaitu sebanyak 160 orang yang terdistribusi ke dalam 5 kelas. Dua kelas dipilih sebagai sampel penelitian dengan teknik cluster random sampling. Kedua kelas selanjutnya diundi untuk menentukan kelas eksperimen dan kelas kontrol. Dari hasil pengundian terpilih kelas XI MIPA2 sebagai kelas eksperimen dan kelas XI MIPA4 sebagai kelas kontrol. Data mengenai kemampuan pemecahan masalah matematika siswa dikumpulkan dengan menggunakan tes essay dan selanjutnya dianalisis dengan menggunakan uji-t satu ekor pada taraf signifikansi $5 \%$. Hasil analisis menunjukkan $t_{\text {hitung }}=$ 2,0714 dan $t_{\text {tabel }}=1,67022$ yang berarti bahwa model pembelajaran kooperatif tipe TAPPS berbantuan LKS open-ended berpengaruh positif terhadap kemampuan pemecahan masalah matematika siswa.
\end{abstract}

Kata kunci : TAPPS, pemecahan masalah matematika, LKS open-ended

\begin{abstract}
Abstrac
This research was a quasi-experimental research that aimed to determine the effect of TAPPS cooperative learning model assisted by an open-ended student's worksheet toward the student's mathematical problem solving skills of XI MIPA in SMA Negeri 2 Banjar. The research design of this study was post-test only control group design. The populations of this research were the students of XI MIPA in SMA Negeri 2 Banjar at the first semester of academic year 2018/2019 which consisted of 160 students which was distributed into 5 classes. Two classes were selected as research samples with cluster random sampling technique, XI MIPA2 class as the experimental class and the XI MIPA4 class as the control class. The data of students' mathematical problem solving skills were collected by essay test and it was analyzed by using t-test one tail with $5 \%$ of significant level. The result of this research shows that the $t_{\text {value }}=2,0714$ and $t_{\text {table }}=1,67022$. It means that the TAPPS cooperative learning model assisted by an open-ended student's worksheet have positive effect to the students' mathematical problem solving skills.
\end{abstract}

Keywords: TAPPS, mathematic problem solving skills, open ended student's worksheet

\section{PENDAHULUAN}

Matematika merupakan salah satu mata pelajaran yang sangat penting dalam perkembangan teknologi dan industri masa kini. Menurut Permendikbud RI No. 59 tahun 2014, matematika merupakan ilmu universal yang mendasari perkembangan teknologi modern, mempunyai peran penting dalam berbagai disiplin, dan memajukan daya pikir manusia. Oleh karena itu, matematika diberikan kepada semua siswa mulai dari jenjang sekolah dasar hingga perguruan tinggi, bertujuan untuk membekali mereka dengan kemampuan berfikir logis, analitis, sitematis, kritis, kreatif dan kemampuan bekerjasama (Daryanto, 2012). Pembelajaran matematika disekolah memiliki tujuan umum yang tercantum dalam Permendikbud RI No.59 Tahun 2014, salah satunya yaitu menggunakan 
penalaran pada sifat, menentukan manipulasi matematika baik dalam penyederhanaan, maupun menganalisa komponen yang ada dalam pemecahan masalah dalam konteks matematika maupun di luar matematika (kehidupan nyata, ilmu, dan teknologi) yang meliputi kemampuan memahami masalah, membangun model matematika, menyelesaikan model dan menafsirkan solusi yang diperoleh termasuk dalam rangka memecahkan masalah dalam kehidupan sehari-hari (dunia nyata).

Selain itu, Menurut NCTM (2000) merumuskan tujuan pembelajaran matematika terdiri dari lima kemampuan dasar matematika yang merupakan standar yakni pemecahan masalah (problem solving), penalaran dan bukti (reasoning and proof), komunikasi (communication), koneksi (connections), dan representasi (representation). Berdasarkan tujuan pembelajaran matematika yang terdapat dalam Permendikbud RI No.59 Tahun 2014 dan NCTM (2000) bahwa kemampuan pemecahan masalah merupakan salah satu aspek yang ditekankan dalam pembelajaran matematika.

Kemampuan pemecahan masalah merupakan kemampuan seseorang dalam menyelesaikan soal-soal tidak rutin dimana solusinya tidak diperoleh secara langsung tetapi siswa memerlukan proses bernalar, menduga, atau memprediksi, mencari rumusan sederhana untuk menemukan solusinya (Suherman, 2003). Menurut Aisyah (dalam Siskawati, 2013) bahwa pembelajaran akan lebih terarah apabila dimulai dengan permasalahan yang harus dipecahkan siswa. Situasi yang menuntut siswa mampu memecahkan masalah akan mendorong siswa untuk dapat mengembangkan kemampuan berpikir secara maksimal. Dalam proses penyelesaian masalah siswa dapat menggunakan empat langkah berikut (1) memahami masalah, (2) merencanakan penyelesaian, (3) menyelesaikan masalah sesuai rencana langkah kedua, (4) memeriksa kembali hasil yang diperoleh (Polya, 1954). Menurut Parwati (2012) menyatakan bahwa tujuan pemecahan masalah matematika bukan semata-mata terfokus pada menemukan satu jawaban yang benar, tetapi bagaimana mengonstruksi segala kemungkinan jawaban yang reasonable, beserta segala kemungkinan prosedur dan argumentasinya, mengapa jawaban tersebut masuk akal.

Meskipun kemampuan pemecahan masalah matematika dianggap sangat penting, namun implementasinya dalam pembelajaran matematika masih mengalami kendala, sehingga hasilnya masih jauh dari memadai. Gambaran mengenai rendahnya kemampuan pemecahan masalah matematika siswa dapat dilihat dari hasil studi PISA (Programme International for Student Assesment) pada tahun 2015 yang menyatakan bahwa Indonesia pada bidang matematika berada pada peringkat 62 dari 70 negara dengan rata-rata skor yakni 386, sedangkan rata-rata skor Internasional PISA yakni 500 (OECD, 2015). Literasi yang dinilai melalui soal-soal PISA mengarah kepada kemampuan pemecahan masalah siswa yakni kemampuan siswa dalam merumuskan, menerapkan dan menafsirkan matematika dalam berbagai konteks, kemampuan melakukan penalaran secara matematis dan menggunakan konsep, prosedur dibandingkan dengan soal-soal yang mengukur kemampuan teknis baku yang berkaitan ingatan atau perhitungan yang kebanyakan siswa mudah melakukannya. Salah satu faktor penyebab rendahnya skor rata-rata matematika siswa dalam tes PISA, karena siswa masih belum terbiasa menyelesaikan soal-soal sesuai dengan konteks PISA. Dimana soal-soal PISA didominasi oleh soal non rutin yang menuntut siswa berfikir tingkat tinggi.

Menurut Siskawati,dkk (2013) rendahnya kemampuan pemecahan masalah siswa juga dipengaruhi oleh beberapa faktor dalam proses pembelajaran dikelas diantaranya adalah sebagai berikut. Pertama, dalam proses pembelajaran di kelas guru hanya berpusat pada target ketuntasan materi saja, dibandingkan dengan penguasaan materi sehingga siswa cenderung menghafalkan materi dan sulit menemukan atau mengaitkan materi yang dipelajari dalam memecahkan masalah matematika. Pembelajaran seperti ini mengakibatkan siswa mengingat konsep dalam jangka pendek saja, tetapi gagal 
dalam jangka panjang. Kedua, penyajian masalah matematika lebih di dominasi oleh soal-soal rutin. Penyajian soal dalam rutin biasanya akan menyebabkan siswa dengan mudah menebak dan mendapat solusinya, tanpa melalui proses mengerti. Sebaliknya, siswa akan mengalami masalah atau gagal mengerjakan soal matematika, jika soalnya sedikit dirubah atau jika konteksnya dibuat sedikit berbeda dari contoh-contoh yang telah diberikan. Oleh karena itu dalam memecahkan masalah siswa cenderung terpaku pada contoh-contoh penyelesaian masalah yang diberikan oleh guru. Siswa jarang diberikan kesempatan untuk mengkonstruksi pengetahuannya sehingga hal ini menyebabkan rendahnya kemampuan pemecahan masalah matematika siswa.

Oleh karena itu, guru perlu merancang pembelajaran yang aktif yang tidak membosankan dan dapat membuat siswa lebih lama mengingat konsep. Pemahaman konsep yang baik akan memudahkan siswa memecahkan permasalahan yang bersifat rutin maupun non rutin. Sehingga diperlukan usaha dari guru untuk menumbuhkembangkan kemampuan pemecahan masalah dengan menerapkan pembelajaran inovatif yang tepat (Sugiyanto, 2008). Salah satu model pembelajaran yang dapat diterapkan untuk meningkatkan kemampuan pemecahan masalah siswa adalah model pembelajaran kooperatif tipe thinking aloud pair problem solving (TAPPS).

Menurut Barkley dkk (dalam Setiawati, 2015) model pembelajaran kooperatif tipe TAPPS merupakan model pembelajaran kooperatif dimana siswa mengerjakan permasalahan yang diberikan secara berpasangan, dengan satu anggota pasangan berperan sebagai problem solver dan yang lainnya berperan sebagai listener. Siswa yang berperan sebagai problem solver bertugas untuk mengucapkan semua pemikiran dan mencari solusi untuk memecahkan masalah, sedangkan siswa yang bertugas sebagai listener mendengarkan semua yang dijelaskan problem solver dan memberikan pertanyaan ataupun kritikan terkait dengan jawaban yang disampaikan oleh problem solver. Dengan diberikan tanggung jawab masing- masing, siswa akan aktif dalam pembelajaran sehingga kelompok tidak lagi didominasi oleh beberapa siswa saja. Model pembelajaran kooperatif tipe TAPPS berorientasi pada kemampuan berpikir konstruktivisme yang menghendaki bahwa pengetahuan dibentuk sendiri oleh individu dan pengalaman merupakan kunci utama dari belajar bermakna.

Model pembelajaran ini melatih siswa untuk memecahkan masalah dan merangsang perkembangan kemampuan berpikir siswa secara kreatif dan komunikatif, serta membantu siswa agar lebih memahami materi pembelajaran dengan membiasakan siswa menghadapi dan memecahkan masalah secara terampil. Agar penerapan model pembelajaran kooperatif tipe TAPPS dapat berjalan dengan lebih maksimal, maka diperlukan perangkat pembelajaran yang mendukung pelaksanaannya. Salah satunya adalah dengan menggunakan LKS open-ended. LKS open-ended yang dimaksud adalah LKS yang didalamnya menggunakan masalah matematika terbuka (open-ended). Menurut Sudiarta (2005) menyatakan bahwa masalah matematika open-ended adalah masalah matematika yang dirumuskan sedemikian rupa, sehingga memiliki beberapa atau bahkan banyak solusi yang benar, dan terdapat banyak cara untuk menentukan solusinya. Melalui bantuan LKS open-ended, akan memberikan kesempatan bagi siswa untuk mengembangkan ide/gagasannya untuk menemukan strategi pemecahan masalah sesuai dengan kemampuan yang dimiliki. sehingga siswa lebih mementingkan proses daripada hasil yang bermuara nantinya pada peningkatan pemecahan masalah matematika siswa.

Beberapa penelitian telah dilakukan dengan menggunakan model pembelajaran kooperatif tipe TAPPS salah satunya adalah penelitian yang dilakukan oleh Murti Ayu (2015) menyatakan bahwa kemampuan pemahaman matematis siswa yang dibelajarkan dengan menggunakan model pembelajaran TAPPS lebih baik daripada kemampuan pemahaman matematis siswa yang mengikuti pembelajaran konvensional. Kemampuan pemahaman matematis siswa yang baik dibutuhkan dalam memecahkan suatu masalah matematika nantinya. 
Sehingga ada kemungkinan bahwa model pembelajaran kooperatif tipe TAPPS dapat meningkatkan kemampuan pemecahan masalah matematika siswa.

Berdasarkan pemaparan tersebut, maka peneliti ini bertujuan Untuk mengetahui apakah kemampuan pemecahan masalah siswa yang mengikuti model pembelajaran kooperatif tipe TAPPS berbantuan LKS open-ended lebih tinggi daripada kemampuan pemecahan masalah siswa yang mengikuti pembelajaran dengan model pembelajaran konvensional.

\section{METODE}

Penelitian ini merupakan penelitian eksperimen semu (quasi experimen). Penelitian eksperimen semu digunakan untuk melihat pengaruh yang ditimbulkan dari perlakuan berbeda yang diberikan kepada masing-masing kelompok, dimana peneliti tidak dapat mengontrol semua variabel dan kondisi eksperimen secara ketat (Sugiyono, 2009). Populasi dalam penelitian ini adalah seluruh siswa kelas $\mathrm{XI}$ MIPA SMA Negeri 2 Banjar tahun pelajaran 2018/2019. Banyaknya populasi dalam penelitian ini adalah 160 siswa yang terdistribusi dalam 5 kelas. Pengambilan sampel dilakukan dengan teknik cluster random sampling yakni dengan memilih dua kelas secara random sebagai sampel penelitian. Dua kelas yang digunakan sebagai sampel penelitian yakni kelas XI MIPA2 dan XI MIPA4. Setelah dilakukan penarikan sampel, peneliti melakukan penyetaraan terhadap kedua kelompok sampel untuk mengetahui apakah kedua kelompok sampel tersebut memiliki kemampuan setara atau tidak.

Data yang digunakan dalam melakukan uji kesetaraan antara kelas XI MIPA2 dan XI MIPA4 adalah nilai ulangan akhir semester matematika kelas X MIPA semester genap tahun pelajaran 2017/2018. Uji yang digunakan adalah Uji-t dua ekor untuk dua sampel dengan menggunakan taraf signifikan 5\%. Berdasarkan perhitungan yang dilakukan, diperoleh nilai $t_{\text {hitung }}=1,20179$ dan $t_{\text {tabel }}=t_{(0,975)(61)}=1,9996, \quad$ sehingga $\left|t_{\text {hitung }}\right|<t_{\text {tabel }}$ yang berarti kemampuan matematika kedua kelas tidak berbeda (kemampuan setara).

Setelah diperoleh kemampuan matematika kedua kelompok setara dengan menggunakan data nilai UAS matematika siswa, maka kemudian diundi kembali untuk menentukan kelas eksperimen dan kelas kontrol.

Hasilnya adalah terpilih kelas XI MIPA2 sebagai kelas eksperimen dan XI MIPA4 sebagai kelas kontrol. Pada kelas eksperimen diterapkan model pembelajaran kooperatif tipe TAPPS berbantuan LKS Open-ended sedangkan pada kelas kontrol diterapkan pembelajaran konvensional. Rancangan penelitian yang dilakukan adalah Post Test Only Control Design. Adapun instrumen yang digunakan yaitu tes essay (uraian) pemecahan masalah matematika. Sebelum dilakukan post test tes pemecahan masalah. Instrumen penelitian dikonsultasikan terlebih dahulu dengan guru dan dosen pembimbing untuk diuji cobakan, uji analisis validitas isi (uji pakar) menggunakan pengujian validitas menurut Gregory dan diperoleh validitas isi sebesar 1,00 yang menunjukan bahwa instrumen penelitian memiliki angka validitas sangat tinggi atau dengan kata lain instrumen sangat relevan untuk digunakan.

Tes pemecahan masalah diujicobakan di SMA Negeri 1 Busungbiu sebanyak 5 butir soal kemudian diuji validitas konstruk butir dengan menggunakan rumus korelasi product moment $\left(r_{x y}\right)$ diperoleh 4 butir soal yang valid dari 5 soal yang diujicobakan, selanjutnya dilakukan uji reabilitas tes menggunakan rumus Alpha Cronbach diperoleh 0,622 yang termasuk dalam kategori tes pemecahan masalah termasuk dalam kategori reliabilitas tinggi sehingga soal-soal tersebut layak untuk digunakan

Hipotesis yang diajukan pada penelitian ini yaitu Kemampuan pemecahan masalah matematika siswa kelas XI MIPA SMA Negeri 2 Banjar yang mengikuti pembelajaran dengan model pembelajaran kooperatif tipe TAPPS berbantuan LKS Open-ended lebih tinggi daripada kemampuan pemecahan masalah matematika siswa yang dibelajarkan dengan pembelajaran konvensional. 


\section{HASIL DAN PEMBAHASAN}

A. Hasil Penelitian

Dari data yang telah terkumpul diperoleh bahwa rata-rata skor pemecahan masalah matematika siswa pada kelompok eksperimen adalah 25,88 dan rata-rata skor pemecahan masalah matematika siswa pada kelompok kontrol adalah 22,26. Rangkuman hasil analisis data pemecahan masalah matematika siswa pada kelompok eksperimen dan kelompok kontrol ditunjukkan pada tabel 1 berikut.

Tabel 1. Rangkuman Hasil Analisis Data Pemecahan Masalah Matematika Siswa.

\begin{tabular}{|c|c|c|c|}
\hline \multirow[t]{2}{*}{ No. } & \multirow[t]{2}{*}{ Variabel } & \multicolumn{2}{|c|}{$\begin{array}{c}\text { Skor Kemampuan } \\
\text { Pemecahan Masalah } \\
\text { Matematika (Post-Test) }\end{array}$} \\
\hline & & $\begin{array}{l}\text { Kelompok } \\
\text { Eksperimen }\end{array}$ & $\begin{array}{c}\text { Kelompok } \\
\text { Kontrol }\end{array}$ \\
\hline 1 & $N$ & 32 & 31 \\
\hline 2 & $\bar{X}$ & 25,88 & 22,26 \\
\hline 3 & $S$ & 4,90 & 5,32 \\
\hline
\end{tabular}

Berdasarkan Tabel 1 terlihat bahwa rata-rata skor kemampuan pemecahan masalah matematika siswa kelompok eksperimen yang mengikuti pembelajaran menggunakan model pembelajaran kooperatif tipe TAPPS berbantuan LKS open-ended lebih tinggi dari pada rata-rata nilai kemampuan pemecahan masalah matematika siswa kelompok kontrol yang mengikuti pembelajaran konvensional. Selain itu dapat dicermati pada Gambar 1 Boxplot kelompok eksperimen dan kontrol.

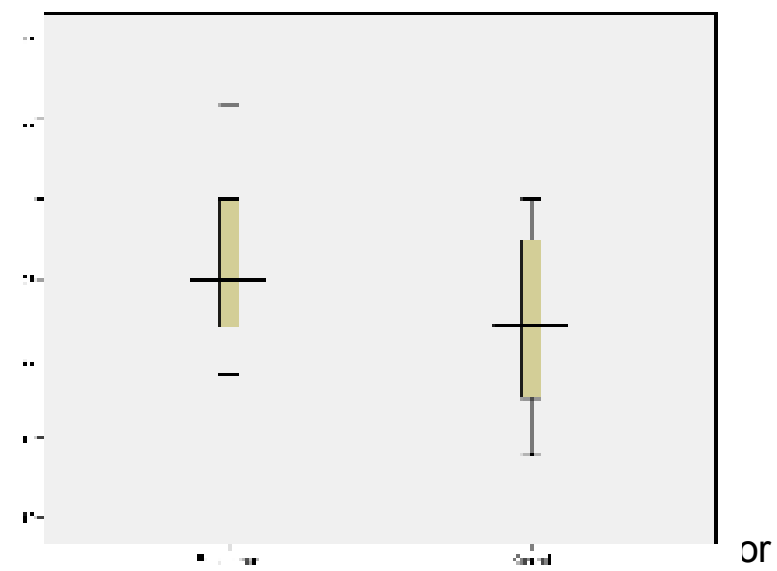

aan varıansı skor kemampuan pemecanan masalah matematika siswa kelompok kelas eksperimen dan kelompok kelas kontrol.

Untuk mengetahui pengaruh penerapan model pembelajaran kooperatif tipe TAPPS berbantuan LKS open-ended terhadap kemampuan pemecahan masalah matematika siswa, dilakukan pengujian hipotesis. Sebelum uji hipotesis dilakukan, terlebih dahulu dilakukan pengujian prasyarat terhadap sebaran data yang meliputi uji normalitas dan uji homogenitas. Hasil uji normalitas dengan menggunakan uji Kolmogorov-Smirnov diperoleh hasil perhitungan normalitas yang ditunjukkan pada Tabel 2 .

Tabel 2. Rangkuman Hasil Uji Kolmogorov-Smirnov 


\begin{tabular}{|c|c|c|c|}
\hline Kelas & D hitung & $D_{\text {tabel }}$ & Keterangan \\
\hline Eksperimen & 0,177 & 0,240 & $\begin{array}{l}\text { Berdistribusi } \\
\text { normal }\end{array}$ \\
\hline Kontrol & 0,143 & 0,244 & $\begin{array}{c}\text { Berdistribusi } \\
\text { normal }\end{array}$ \\
\hline
\end{tabular}

Berdasarkan Tabel 2 diperoleh bahwa $\quad D_{\text {hitung }}<D_{\text {tabei }}$ maka dapat disimpulkan sebaran data kemampuan pemecahan masalah matematika siswa kelompok eksperimen dan kelompok kontrol berdistribusi normal.

Selanjutnya dilakukan Uji homogenitas, yang dimaksudkan untuk melihat apakah dua atau lebih kelompok data sampel berasal dari populasi yang memiliki variansi sama atau tidak. Untuk menguji homogenitas varians pada penelitian ini digunakan Uji F. Hasil uji homogenitas varians data kemampuan pemecahan masalah matematika siswa dapat dilihat pada Tabel 3.

Tabel 3. Rangkuman Hasil Uji Homogenitas

\begin{tabular}{ccc}
\hline $\boldsymbol{F}_{\text {hitung }}$ & $\boldsymbol{F}_{\text {tabel }}$ & Keterangan \\
\hline 1,1753 & 2,0657 & Homogen \\
\hline
\end{tabular}

Berdasarkan Tabel 3 maka dapat disimpulkan tidak ada perbedaan varian antara kelompok eksperimen dan kelompok kontrol (varian data homogen).

Berdasarkan hasil uji normalitas dan homogenitas varians, diperoleh bahwa sebaran data kemampuan pemecahan masalah matematika siswa pada kelompok eksperimen dan kelompok kontrol berdistribusi normal dan memiliki varians yang homogen. Oleh karena itu, uji hipotesis dapat dilakukan. Uji hipotesis pada penelitian ini menggunakan uji-t satu ekor dengan taraf signifikan 5\%. Hasil uji hipotesis dapat dilihat pada Tabel 4.

Tabel 4. Rangkuman Hasil Uji Hipotesis

\begin{tabular}{cccc}
\hline Kelompok & $\boldsymbol{D} \boldsymbol{k}$ & $\boldsymbol{t}_{\text {hitung }}$ & $\boldsymbol{t}_{\text {tabel }}$ \\
\hline Eksperimen & 61 & 2,8082 & 1,67022 \\
Kontrol & 61 & & \\
\hline
\end{tabular}

Berdasarkan Tabel 4 diperoleh $t_{\text {hitung }}=$ 2,8724 dan $t_{\text {tabel }}=1,67022$ untuk $d k=n_{1}+n_{2}$ $2=32+31-2=61$ dengan taraf signifikan $5 \%$. Hal ini mengakibatkan $t_{\text {hit }}>t_{\text {tabel }}$ yaitu $2,8082>1,67022$ yang berarti skor kemampuan pemecahan masalah matematika siswa yang dibelajarkan model pembelajaran kooperatif tipe TAPPS berbantuan LKS open-ended lebih tinggi dari skor kemampuan pemecahan masalah matematika siswa yang dibelajarkan dengan pembelajaran konvensional.

\section{B. Pembahasan}

Berdasarkan hasil analisis data, diperoleh bahwa kemampuan pemecahan masalah matematika siswa yang dibelajarkan dengan model pembelajaran kooperatif tipe TAPPS berbantuan LKS 
open-ended lebih tinggi daripada kemampuan pemecahan masalah matematika siswa yang dibelajarkan dengan pembelajaran konvensional. Kemampuan lebih tinggi ini menunjukkan bahwa terdapat pengaruh model pembelajaran kooperatif tipe TAPPS berbantuan LKS open-ended terhadap kemampuan pemecahan masalah matematika siswa.

Hal tersebut dapat terjadi karena model pembelajaran kooperatif tipe TAPPS berbantuan LKS open-ended ini memberikan kesempatan kepada siswa untuk memahami sendiri materi yang diberikan, karena setiap siswa diberikan tanggung jawab masing-masing yaitu sebagai listener dan problem solver. Menurut Stice (dalam Sara 2016) peran dari Problem solver adalah menjelaskan permasalahan dan menyelesaikan permasalahan bersama listener, sedangkan peran listener adalah menanyakan hasil penyelesaian yang dibuat oleh problem solver walaupun listener mengerti ataupun tidak mengerti dari hasil yang dibuat oleh problem solver. Problem solver harus berhadapan dengan listener untuk menyelesaikan secara bersama-sama masalah tersebut.

Berdasarkan pengamatan selama proses penelitian, dapat diamati juga bahwa saat pembelajaran berlangsung dikelas dengan penerapan model pembelajaran kooperatif tipe TAPPS membuat siswa lebih termotivasi, aktif, dan memiliki kemauan lebih dalam belajar matematika karena masing-masing siswa diberikan tanggung jawab sesuai dengan perannya dan suasana dalam proses pembelajaran tidak membosankan. Pada saat pembelajaran guru tidak langsung menjelaskan kepada siswa melainkan siswa sudah terlebih dahulu belajar dirumah sehingga ketika proses pembelajaran berlangsung guru langsung memberikan permasalahan.

Selain itu, juga disebabkan oleh dukungan LKS open-ended yang sangat membantu siswa dalam pembelajaran. Menurut (Parwati,2012:66) "Masalah matematika terbuka memberikan kesempatan bagi siswa untuk melakukan investigasi masalah matematika secara mendalam, sehingga dapat mengonstruksi segala kemungkinan pemecahannya secara kritis, kreatif, divergen, dan produktif". Oleh karena itu, penyajian LKS open-ended memberikan kesempatan kepada siswa untuk mengkontruksi dan menginvestigasi berbagai strategi yang sesuai dengan kemampuan yang dimiliki, sehingga dapat mengembangkan kreativitas berpikir siswa dalam memecahkan masalah, baik masalah rutin maupun non rutin. Informasi yang diberikan dalam masalah open-ended tidak secara lengkap, melainkan hanya beberapa informasi yang berkaitan dengan masalah saja. Sehingga dalam penyelesaiannya siswa membutuhkan pemahaman yang lebih mendalam lagi, yang nantinya dapat melatih kemampuan pemecahan masalah siswa. Selain itu, menurut (Parwati, 2016) bahwa proses pemecahan atau penyelesaian suatu masalah, memerlukan kegiatan mental (berpikir) yang lebih banyak dan kompleks dari pada kegiatan mental yang dilakukan pada waktu menyelesaikan soal-soal rutin. Hal tersebut juga didukung dengan penelitian yang dilakukan oleh Siskawati,dkk (2013) diperoleh bahwa adanya pengaruh positif terhadap kemampuan pemecahan masalah matematika siswa dengan menerapkan LKS open-ended. Pemberian LKS open-ended akan membiasakan siswa untuk berpikir kritis dalam menyelesaikan masalah non rutin yang akhirnya bermuara pada peningkatan kemampuan pemecahan masalah matematika siswa.

Penerapan model pembelajaran kooperatif tipe TAPPS berbantuan LKS open-ended diawali dengan tahap membaca dan memikirkan penyelesaian yakni pada tahap ini siswa diberikan waktu untuk menganalisa dan mengamati hal-hal apa saja yang diketahui, dan ditanyakan dalam permasalahan yang dberikan pada LKS open-ended, serta memikirkan rencana penyelesaian yang digunakan untuk menyelesaikan masalah tersebut. Dengan keterlibatan aktif siswa dalam proses pembelajaran, siswa dapat lebih mudah memahami konsep yang akan dipelajari dibandingkan dengan siswa yang hanya memahami konsep yang diberikan guru tanpa memberikan kesempatan kepada siswa untuk menemukan sendiri konsep tersebut. Pentingnya pemahaman konsep mampu membantu siswa dalam memecahkan masalah, hal ini sejalan 
dengan penelitian yang dilakukan oleh Murti Ayu (2015) diperoleh bahwa adanya pengaruh positif atau meningkatnya pemahaman konsep siswa dengan menerapkan model pembelajaran TAPPS. Pemahaman konsep siswa yang baik maka membantu siswa dalam memahami masalah serta memudahkan siswa menyelesaikan permasalahan yang diberikan.

$$
\text { Tahap kedua adalah }
$$

pengorganisasian kelompok, dimana guru meminta siswa untuk membentuk kelompok secara berpasangan yang terdiri dari 2 orang. Setiap orang dalam satu kelompok akan mendapatkan tanggung jawab masingmasing sesuai dengan perannya. Siswa akan diberikan kesempatan berpartisipasi aktif dalam kegiatan diskusi kelompok untuk menyelesaikan permasalahan yang diberikan dalam LKS open-ended. Kemudian dilanjutkan ke tahap berpasangan, pada tahap ini setiap siswa pada masing-masing kelompok mulai menjalankan perannya masing-masing. Siswa mulai mendiskusikan permasalahan yang diberikan pada LKS open-ended. Siswa yang berperan sebagai problem solver mulai memecahkan permasalahan sesuai dengan strategi yang direncanakan. Selama problem solver menjelaskan penyelesaiannya, listener harus mengamati setiap langkah penyelesaian masalah yang disampaikan serta menanyakan apabila ada hal-hal yang kurang dimengerti dan juga bisa menyampaikan saran dan kritik terhadap penjelasan yang diberikan. Apabila dalam proses pemecahan masalah problem solver mengalami kesulitan, listener dapat mengarahkan problem solver untuk dapat memecahkan masalah dengan memberikan petunjuk-petunjuk yang sesuai.

Tahap selanjutnya adalah bertukar peran, tahap ini mulai dilakukan setelah permasalahan pertama selesai didiskusikan kemudian listener dan problem solver mulai bertukar peran. Setelah bertukar peran listener dan problem solver mulai menjalankan perannya masing-masing untuk menyelesaikan masalah berikutnya yang ada dalam LKS open-ended. Kemudian pembelajaran dilanjutkan dengan Presentasi, setelah semua masalah yang ada telah diselesaikan dan semua anggota pernah berperan sebagai listener dan problem solver. Guru meminta satu kelompok yang terdiri dari listener dan problem solver untuk mempresentasikan hasil diskusi kelompoknya di depan kelas. Kelompok lain yang tidak presentasi diminta untuk memberikan pertanyaan, saran maupun kritikan kepada kelompok yang presentasi. Pada tahap ini guru juga memberikan klarifikasi apabila ada konsep yang kurang tepat sehingga apa yang diterima oleh siswa dalam pembelajaran tidak melenceng dari konsep yang ada. Tahap terakhir adalah penghargaan yang diberikan kepada kelompok terbaik, listener terbaik dan problem solver terbaik yaitu berupa pujian. Penghargaan ini diberikan sesuai dengan hasil pengamatan guru selama proses pembelajaran maupun selama proses diskusi. Hal ini dapat meningkatkan motivasi siswa untuk lebih baik lagi dan meningkatkan semangat dalam proses pembelajaran.

Secara umum pelaksanaan pembelajaran dengan model pembelajaran kooperatif tipe TAPPS berbantuan LKS open-ended berjalan dengan baik dan sesuai rencana. Walaupun demikian dalam pelaksanaannya dikelas tidak luput dari adanya kendala-kendala. Adapun kendalakendala yang dihadapi adalah sebagai berikut.

1. Masih banyak siswa yang kurang memahami perannya masing-masing dalam diskusi kelompok.

2. Siswa sulit menuangkan idenya kedalam bentuk matematis karena masih belum terbiasa maka dari itu siswa perlu diarahkan agar mampu terbiasa dan terlatih menuliskan ide yang dimiliki untuk membuat perencanaan yang sistematis dalam menyelesaikan soal.

3. Pada awal pertemuan ketika mempresentasikan jawaban, siswa masih terlihat malu-malu dan hanya beberapa siswa yang berani mengemukakan pendapatnya.

Namun kendala-kendala tersebut dapat ditangani dengan baik. Kendalakendala tersebut dapat ditangani dengan memberikan penjelasan yang lebih sampai siswa benar-benar mengerti peran dan tanggung jawabnya dalam kelompok. 
Selanjutnya mengingatkan siswa pada setiap pertemuan untuk belajar secara mandiri dirumah terkait materi yang akan dibahas dipertemuan berikutnya. Terakhir memberikan penghargaan berupa pujianpujian dan nilai tambahan kepada siswa dan kelompoknya yang berani mempresentasikan hasil diskusinya didepan kelas, agar siswa lebih termotivasi dalam mengikuti pembelajaran.

Berdasarkan hasil pengujian hipotesis dan gambaran deskriptif masingmasing pembelajaran yang telah diterapkan, dapat dilihat bahwa pembelajaran dengan model pembelajaran kooperatif tipe TAPPS berpengaruh positif terhadap kemampuan pemecahan masalah matematika siswa. Hal tersebut didukung oleh hasil uji hipotesis yang menunjukkan bahwa kemampuan pemecahan masalah siswa yang mengikuti pembelajaran dengan model pembelajaran kooperatif tipe TAPPS lebih tinggi daripada siswa yang mengikuti pembelajaran konvensional.

\section{SIMPULAN}

Berdasarkan hasil penelitian dan hasil analisis data yang telah dibahas sebelumnya maka dapat disimpulkan bahwa kemampuan pemecahan masalah matematika siswa yang dibelajarkan model pembelajaran kooperatif tipe TAPPS berbantuan LKS open-ended lebih tingi dari kemampuan pemecahan masalah matematika siswa yang dibelajarkan dengan pembelajaran konvensional. Dengan kata lain terdapat pengaruh positif model pembelajaran kooperatif tipe TAPPS berbantuan LKS open-ended terhadap kemampuan pemecahan masalah siswa.

\section{SARAN}

Adapun saran yang dapat disampaikan berdasarkan hasil penelitian yang telah dilakukan adalah sebagai berikut. Pertama, Praktisi pendidikan, khususnya pihak-pihak yang terlibat dalam pembelajaran matematika disarankan untuk menggunakan model pembelajaran kooperatif tipe TAPPS berbantuan LKS open-ended sebagai salah satu alternatif pembelajaran di kelas, mengingat perkembangan kurikulum yaitu penerapan kurikulum 2013 yang menuntut tenaga pendidik menerapkan strategi pembelajaran yang lebih inovatif.

. Kedua, Penelitian ini hanya bertujuan untuk mengetahui pengaruh model pembelajaran kooperatif tipe TAPPS berbantuan LKS open-ended dalam pembelajaran matematika terhadap kemampuan pemecahan masalah matematika siswa. Peneliti lain yang tertarik disarankan untuk menguji coba pengaruh strategi ini terhadap aspek pembelajaran yang berbeda, misalnya terhadap kemampuan penalaran, koneksi matematika maupun aspek pembelajaran yang lainnya.

\section{DAFTAR PUSTAKA}

Daryanto dan Mulyo Rahrdjo. 2012. Model Pembelajaran Inovatif. Yogyakarta: Gava Media.

Parwati,N.N. 2012. Pengembangan Perangkat Pembelajaran Matematika Berorientasi OpenEnded Problem Solving. Jurnal IImu Pendidikan. Jilid 1 Nomor 1

Polya, G. 1954. How To Solve It. USA: Princeton University Press. Tersedia pada https://math.hawaii.edu/home/pdf/p utnam/PolyaHowToSolvelt.pdf (diakses pada tanggal 22 April 2018 )

Sara,Yuni N.W. 2016 . Pengaruh Model Pembelajaran Kooperatif Tipe Thinking Aloud Pair Problem Solving (TAPPS) Berbantuan LKS Tertruktur Terhadap Prestasi Belajar Matematika Siswa Kelas VIII Non Unggulan SMPN 4 Singaraja. Skripsi (Tidak Diterbitkan). Jurusan Pendidikan Matematika. FMIPA Undiksha

Siskawati,Pt, dkk. 2013. Pengaruh Model Pembelajaran ICl Berbantuan LKS Open-Ended terhadap Kemampuan Pemecahan Masalah Matematika 
Siswa Kelas V SD. Universitas pendidikan Ganesha

Sudiarta, I G.P. 2005. Pengembangan dan Implementasi Pembelajaran Matematika Berorientasi Pemecahan Masalah Open-Ended di Sekolah Dasar se-Bali. Ringkasan Laporan Penelitian (tidak diterbitkan). Singaraja: Undiksha

Sugiyanto, 2008.

Model-Model Pembelajaran Inovatif. Surakarta: Panitia Sertifikasi Guru Rayon 13.

Sugiyono. 2009. Metode Penelitian Kuantitatif Kualitatif dan $R \& D$. Bandung: CV Alfabeta.

Suherman, Erman dkk. 2003. Strategi Pembelajaran Matematika Kontemporer. Bandung: PT Remaja Rosdakarya.

Setianingrum, Murti Ayu, dkk. 2015. Pengaruh Model Pembelajaran Thinking Aloud Pair Problem Solving (TAPPS) Terhadap Kemampuan Pemahaman Matematis Siswa. Universitas Muhammadiyah Tangerang. Volume 1 Nomor 2

Setiawati, N.L.P, dkk. 2015. Pengaruh Model Pembelajaran Kooperatif Thinking Aloud Pair Problem solving
(TAPPS) Berbantuan LKS Terhadap Sikap Sosial dan Hasil Belajar Matematika Siswa Kelas VI SLB Negeri Gianyar. e-Journal Program Pascasarjana Universitas Pendidikan Ganesha. Volume 5 Nomor 1 